
ALTERNATIVE

3

4

\author{
Damians, I.P. \\ Ph.D., Assistant Professor, Department of Civil and Environmental Engineering, Universitat \\ Politècnica de Catalunya - BarcelonaTech (UPC). Campus Nord UPC, 08034 Barcelona, \\ Spain. Email: ivan.puig@upc.edu

\section{Olivella, S.} \\ Ph.D., Professor, Department of Civil and Environmental Engineering, Universitat Politècnica \\ de Catalunya - BarcelonaTech (UPC). Campus Nord UPC, 08034 Barcelona, Spain. Email: \\ sebastia.olivella@upc.edu
}

\title{
Pintado, $X$.
}

Ph.D., Researcher, Saanio \& Riekkola Oy, Laulukuja 400420 Helsinki, Finland

Email: xavier.pintado@ains.fi

Key words: TH 3D model, Buffer swelling, Gap, KBS-3H, Onkalo

\begin{abstract}
.
The KBS-3H disposal alternative is composed by horizontally placed supercontainers comprising the canisters with the spent nuclear fuel surrounded in both drift axis and radial directions by compacted bentonite blocks (buffer) enclosed in a perforated shell. The different internal gaps between the supercontainer components and the one between the buffer blocks and the host rock have direct effects on the buffer behaviour. This paper presents a ThermoHydraulic (TH) Three-Dimensional (3D) numerical model developed to analyse a particular geometry assuming three different gap state conditions and providing results of the temperature, liquid pressure, and evolution of the degree of saturation.

The material parameters, constitutive models, and assumptions made were carefully selected with regards to laboratory measurements reported in directly-related bibliography. The modelling settles the importance of understanding the groundwater flow through the rock mass and from fractures in the rock in order to achieve reliable predictions regarding buffer saturation, since it is known that the saturation times could range from few years to one thousand years depending on the hydrogeological conditions in the rock. The obtained results lead to full saturation times of 50 to 100 years. In addition to the rock hydraulic conductivity and fracture transmissivity, the saturation process was directly affected by the material properties of the buffer and gap presence between the buffer blocks and the host rock. Finally, in connection with thermal evolution, the thermal conductivity of repository components and the behaviour of air gaps in the buffer were key variables.
\end{abstract}




\section{INTRODUCTION}

Deep geological disposal is an option for the long-term confinement of spent nuclear fuel in many countries employing nuclear power. The current design in Finland (Posiva Oy) and Sweden (SKB AB) is called KBS-3 (SKB 2010a and 2010b). The KBS-3 involves the excavation of a network of tunnels in a crystalline rock and the emplacement of the canisters containing the spent nuclear fuel. These are surrounded by compacted bentonite buffer blocks and bounded by a titanium shell generating the supercontainer. The supercontainers may be emplaced in vertical deposition holes (KBS-3V disposal method, Juvankoski and Marcos, 2010) or in horizontal galleries (KBS-3H alternative, Posiva and SKB 2017). Posiva Oy is developing the final disposal facility in Olkiluoto (Posiva 2009). The current paper presents some results of a thermal-hydraulic (TH) 3D numerical model which are part of the assessment for the KBS-3H alternative repository design. This model has been developed in order to analyse the temperature and the saturation evolution of a spent nuclear fuel disposal scheme with emplacement of several (and same-type) canisters in a drift. Three different gap state conditions between the buffer blocks, surrounded by the supercontainer shell, and the host rock have been assumed in KBS-3H design alternative (Posiva and SKB 2017; Pintado et al. 2016a). This paper summarizes and extends some of the results presented in Pintado et al. (2016b).

In the last decades, a lot of effort has been put in the understanding of the thermo-hydromechanical processes in spent nuclear fuel underground disposal. Several disposal geometries have been discussed, modelled and analysed. Two "in situ" tests related with the horizontal canister disposal are going to be commented. The FEBEX experiment performed in Grimsel Test Site (Enresa 2000) is a full scale experiment that reproduces the disposal of two canisters characterized by heaters in granitic rock isolated by bentonite compacted blocks. Gens et al. (1998 and 2009) have carried out thermo-hydro-mechanical calculations, both predictive and operational. The understanding of the phenomena and the predictive capabilities are significant. Note that 1D THM calculations were carried out for the predictive studies (Gens et al. 1998). For the operational phase, 2D THM (axisymmetric) calculations were carried out and this permitted to represent the 2 heaters and later on to simulate the material with double structure concerning micro and macro structure (Gens and Alonso 1992; Sánchez et al. 2016) and include operational activities related with the test protocols. In the transit from 1D to 3D THM models an intermediate stage is to carry out TH calculations. Development of 3D geometries has several added values, for instance, non-axisymmetric features can be incorporated (this is the case of arbitrarily oriented fractures). Another "in situ" test directly related with the KBS-3H alternative is currently being carried out in Äspö (Pintado et al. 2015 and 2016a). This test reproduces the KBS-3H alternative in full scale although it is an isothermal test (the canister is reproduced by a metal cylinder).

During these decades of research, numerical tools have been developed and improved in order to facilitate numerical model development at a relatively low effort. CODE_BRIGHT (Olivella et al. 1996; DECA-UPC / CIMNE 2017) is a computer code that solves the nonisothermal multiphase flow in deformable porous media. In this work, only the coupled equations of balance of water and energy (as a particular case of a more general formulation) have been solved. For performing the modelling work, it is necessary to use appropriate constitutive equations (Darcy, Fick, Fourier, Van Genuchten, among others) and equilibrium restrictions for liquid water and vapour. CODE_BRIGHT can be used in the framework of 
GiD (GID-CIMNE 2017), so several pre-process capabilities are available. Development of the 3D representation of the canister and buffer components in a fractured rock can be done with GiD.

\section{MODEL GEOMETRY AND MAIN FEATURES}

A 3D thermal and hydraulic $(\mathrm{TH})$ model was developed in order to study the behaviour of the entire drift geometry KBS-3H alternative (Figures 1-3). The KBS-3H model includes the supercontainers (where canisters are placed in), the intersections with three fractures (which provide water due to their higher permeability; see Figure 1), and the filling material (Figures 2 and 3). The model generated allowed to analyse the magnitudes and evolution of the temperature, liquid pressure, and degree of saturation at any point in the defined domain up to 1000 years from the emplacement of the canisters.

The drift was assumed to be placed at $425 \mathrm{~m}$-depth. The drift was considered open during one year after the excavation and the atmospheric pressure was imposed on the internal drift surfaces as boundary condition. Eight canisters (and related components) were assumed to be serially distributed and horizontally arranged (with $2^{\circ}$ tilt). The lateral distance between drift axes was fixed to be $25 \mathrm{~m}$ (Posiva and SKB 2017). Thus, the model domain was consequently $25 \mathrm{~m}$-width (i.e., $12.5 \mathrm{~m}$ distance from drift centre to lateral boundary sides, acting as symmetry planes with regards to subsequent drifts). The total length of the drift is about 107 $\mathrm{m}$ and the separation between the eight supercontainers varies from $3.5 \mathrm{~m}$ up to $16 \mathrm{~m}$. This separation depends on the presence of fractures in the rock and fracture orientation relative to the drift axis. The description of how to deal with fractures intersecting the drifts is also described in Posiva and SKB (2017). The minimum distance between supercontainers is due to thermal conditions. The maximum temperature of the canister and the surrounding buffer blocks cannot be more than $100^{\circ} \mathrm{C}$, which corresponds to a safety requirement (Ikonen and Raiko 2015; STUK 2015).

Two domain geometries were developed with regard to the vertical distance to the boundaries: the preliminary and the final "best-fit" one. The preliminary model was assumed to have $20 \mathrm{~m}$ rock-thickness above and below the drift (see Figure 1a). However, as it is explained in Section 4.1, this distance was considered not adequate as the prescription of temperature (and pressure) was too close to the zone of interest (i.e., top and bottom horizontal boundary planes located too close to the drift). Because of this issue, it was decided to increase the model geometry up to $100 \mathrm{~m}$ rock-thickness above and below the drift (i.e., to locate the horizontal top and bottom boundaries further away; see Figure 1b) with a mixed boundary condition with $10.5^{\circ} \mathrm{C}$ of temperature and coefficient of heat transfer equal to 0.05 $\mathrm{W} /\left(\mathrm{m}^{2} \mathrm{~K}\right)$. The geothermal gradient has not been included in this model, as the actual temperature variation between boundary surfaces would be insufficient to produce an effect on the results (Posiva 2012). This $100 \mathrm{~m}$ vertical distance-to-boundaries assumption was determined to be large enough in order to assure the proper temperature dissipation (Toprak et al. 2013). Despite the non-suitable preliminary geometry, some temperature generation results are also provided to compare with the final one.

The drift is composed by a series of material components, called filling blocks or distance blocks, installed between supercontainers (see Figure 2a) to horizontally fill the drift. 
1 Supercontainers are filled by buffer blocks surrounding the canisters; laterally by ring

2 sections, and longitudinally by cylinder sections (see Figure 2c).

3 Due to the variable canisters spacing and distances to the intersection with rock fractures, the 4 proposed geometry was expected to return a kind of "real case" response as compared to a 5 single canister 3D or 2D-axysimetric models. However, due to the relatively large domain 6 modelled, some restrictions and simplifications were required. As a first step, this problem was solved and presented in this study without mechanical equations. Instead, a simplified approximation for the closing gap evolution treatment was considered which is explained below.

In the real basic geometry and material component arrangement, there is a perforated metal (titanium) shell to keep the canister and the surrounding buffer blocks together. Between this shell and the host rock, an open-gap is initially maintained at all the perimeter outline of the cylinder with about $44.5 \mathrm{~mm}$-thick (see Figure 3, and Posiva and SKB 2017 for more details about the actual geometry of the supercontainer and KBS-3H geometry). The same $44.5 \mathrm{~mm}$ gap thickness was considered in the model. It is known that, after a certain level of heating and buffer hydration and swelling, the blocks will tend to extrude through the bored metal shell filling the gap at all the contour (see Sandén et al. 2008 and Kristensson et al. 2016 for the so-called Big Berta mock-up tests, and Asensio 2013 for the study of the bentonite extrusion through the holes of the supercontainer). Thus, a material model geometry distinction was made to distinguish the inner from the outer part of the buffer (as detailed in Figure 3; dashed line).

Following the description above, it was decided to build three different cases for the $\mathrm{TH}$ modelling providing variants to material parameters for the buffer (inner/outer) and for the gap component (see Tables 1 and 2; commented in the following material properties section). The same fixed model geometry and 3D finite element model mesh was considered (this excludes differences attributed to slightly different mesh configurations).

The three proposed cases correspond to the evolution of the system according to the different state conditions at the beginning of the calculations with respect to gap aperture (open or closed gap) and properties of the outer buffer material (different or equal to the inner buffer material, otherwise equal or different to the gap material). The three states are referred to:

- Installation state: when the filling components are installed, thus corresponding to a very short-term evolution.

- Initial state: when buffer is swollen and the gap between rock and supercontainer is closed, corresponding to a short- and mid-term evolution.

- Homogenized state: long-term evolution, assuming that the buffer and the gap materials area is fully homogenized.

These three cases are schematically represented in Figures $3 a, 3 b$, and $3 c$, respectively. Further explanation about these three configurations in terms of the material properties assumed is given in material properties following section and related Tables 1 and 2.

The final model is composed by 105170 nodes defined from 619865 tetrahedron elements. A single simulation run requires about of 35 hours ( 1 core) and 20 hours $(2$ cores, parallel 
computing OpenMP) of calculation time in an Intel® Core ${ }^{\mathrm{TM}}$ i7-4790 CPU @ 3.60 GHz work station processor with 8 GB RAM memory.

\section{MATERIAL PROPERTIES}

Table 1 presents the material properties at initial conditions for Installation, Initial and Homogenized state cases. Details of the adopted parameter values of the materials can be found in Pintado et al. 2016a,b.

Besides the mentioned average $45 \mathrm{~mm}$-thick gap, two other smaller gaps parallel to the drift axis are present in the real basic supercontainer geometry. One is expected to be $5.1 \mathrm{~mm}$ thick, separating the canister and the buffer blocks, and another one is expected to be $5.5 \mathrm{~mm}$ thick, which separates the buffer blocks and the $6 \mathrm{~mm}$-thick titanium shell (Ikonen and Raiko 2015). None of these two are modelled explicitly in the current study. However, the effect of these thin gaps in the buffer thermal conductivity was incorporated by the equivalent (harmonic mean) thermal conductivity of the gap and buffer (actually ranging from $\lambda_{\text {dry }}=$ $0.025 \mathrm{~W} /(\mathrm{mK})$ to $\lambda_{\text {sat }}=0.6 \mathrm{~W} /(\mathrm{mK})$ for the gap, and $\lambda_{\text {dry }}=0.3 \mathrm{~W} /(\mathrm{mK})$ to $\lambda_{\text {sat }}=1.3 \mathrm{~W} /(\mathrm{mK})$ for the buffer). The equivalent thermal conductivity is calculated assuming steady state heat radial flow.

Temperature variation in a radial steady state flow through a three layer annulus is expressed as a sum of each layer temperature variation:

$$
\frac{Q}{2 \pi \lambda_{e q}} \ln \left(\frac{r_{4}}{r_{1}}\right)=\frac{Q}{2 \pi \lambda_{12}} \ln \left(\frac{r_{2}}{r_{1}}\right)+{\frac{Q}{2 \pi \lambda_{23}}}^{\Delta T_{23}:} \ln \left(\frac{r_{3}}{r_{2}}\right)+{\frac{Q}{2 \pi \lambda_{34}}}^{\Delta T_{34}:} \ln \left(\frac{r_{4}}{r_{3}}\right)
$$

This permits to calculate the equivalent thermal conductivity for an equivalent single buffer block material including the two mentioned boundary gaps as:

$$
\lambda_{e q}=\frac{\ln \left(\frac{r_{4}}{r_{1}}\right)}{\frac{1}{\lambda_{12}} \ln \left(\frac{r_{2}}{r_{1}}\right)+\frac{1}{\lambda_{23}} \ln \left(\frac{r_{3}}{r_{2}}\right)+\frac{1}{\lambda_{34}} \ln \left(\frac{r_{4}}{r_{3}}\right)}
$$

Where $r_{1}$ and $r_{4}$ correspond to the radius up to the boundary of the canister and buffer block, respectively i.e., $r_{1}=525 \mathrm{~mm}$ and $r_{4}=874.5 \mathrm{~mm}$. The value of $r_{4}$ takes into account the above mentioned $6 \mathrm{~mm}$-thick of the non-modelled titanium shell, i.e., $r_{4}=880.5 \mathrm{~mm}-6 \mathrm{~mm}$ (see Figure $3 \mathrm{a}$ ). On the other hand, $r_{2}$ and $r_{3}$ consider the mentioned non-modelled gaps, i.e., $r_{2}=$ $r_{1}+5.1 \mathrm{~mm}$, and $r_{3}=r_{4}-5.5 \mathrm{~mm}$.

The thermal conductivity values considered in Equation 2 are: $\lambda_{12}$ (gap) $=\lambda_{34}$ (gap) $=0.025$ $\mathrm{W} /(\mathrm{mK})$ or $0.6 \mathrm{~W} /(\mathrm{mK})$ for dry or saturated gap, respectively; and $\lambda_{23}$ (buffer) $=0.3 \mathrm{~W} /(\mathrm{mK})$ or $1.3 \mathrm{~W} /(\mathrm{mK})$ for dry or saturated buffer, respectively). With these values, the equivalent thermal conductivities resulted in $\lambda^{d r y}{ }_{e q}=0.223 \mathrm{~W} /(\mathrm{mK})$ for the dry conditions, $\lambda^{\text {sat }}{ }_{e q}=1.254$ $\mathrm{W} /(\mathrm{mK})$ for the saturated conditions, as presented in Table 1. 
As explained in the previous section, a $45 \mathrm{~mm}$-thick open-gap was modelled (as seen in Figure $2 b$ and dimensions detail in Figure $3 a$ ) between the buffer and the rock. This open-gap is a specific characteristic of the Installation state.

However, as mentioned, due to the buffer block expansion (swelling) consequent with the hydration process, the gap was modelled with reduced-porosity properties from the ones defining the original buffer (see Figure 3b). This is a specific characteristic of the Initial state. This permits to perform the closed-gap case due to the swollen buffer blocks. According to this, a $59.5 \mathrm{~mm}$-thick outer portion of buffer was considered to have similar properties as the closed-gap (outer buffer thickness $=880.5 \mathrm{~mm}-821 \mathrm{~mm}$; see Figure $3 \mathrm{~b}$ ). Calculations at this Initial state assume that the bentonite has extruded from the supercontainer and the material which fills the gap can be considered as a solid. Part of the material inside the supercontainer (outer buffer) has the same properties as the closed gap, and the rest of the block thickness (inner buffer) remains unchanged. This is a simplification to perform the mechanical gap filling process, which is a very important concept. The experimental evidences (Sandén et al. 2008; Kristensson et al. 2016; Asensio 2013) indicate that the gap between rock and supercontainer is closed relatively fast and its initial conditions can be measured experimentally, which allows the proper modelling of the Initial state conditions (short- and mid-term context). The gap filling process is a complex 3D problem and the evolution from the installation state to the initial state cannot currently be simulated. However, the conditions at the initial state can be determined based on the experiments.

Finally, a third case referred to Homogenized state assumes that the material of the buffer blocks (inner and outer) and the closed gap has the same density. This is assumed to correspond to a long-term state of the buffer material (see Figure 3c). Under this long-term analysis case, both inner and outer buffer block zones, in addition to the closed-gap, share the same porosity and derived properties (permeability and diffusivity). The material properties of the parts of the buffer for the three different states discussed above are presented in Table 2.

Figure 4 shows the decay power function imposed in canisters. The original and first approach power law (data points reported by Ikonen and Raiko 2015) was improved in order to avoid straight trends between time intervals and provides smoother temperature variation as a result. The function begins at $t=1$ year and gives approximately $410 \mathrm{~W} / \mathrm{m}^{3}$ (equivalent to about $1700 \mathrm{~W} /$ canister).

\section{RESULTS}

\subsection{Temperature results}

As mentioned above, the model geometry dimensions were increased up to $\pm 100 \mathrm{~m}$ with regard to the preliminary model that was $\pm 20 \mathrm{~m}$ distance to top and bottom boundary planes (Figures 1a and 1b).

Different evolution of variables was obtained when comparing the $\pm 20 \mathrm{~m}$ model and the \pm 100 $\mathrm{m}$ model. The comparison for domain size was only carried out for the short- and mid-term Initial state. Figure 5 displays the temperature distribution along the drift axis for the two geometrical configurations. A first observation from these results is the effect of the canister 
separation. Higher temperature is reached when the canisters are close to each other (i.e., canisters \#2 to \#4). In contrast, canister \#6 (which is the most spaced due to the presence of rock fractures) and canister \#8 (which is the last one in the drift) develop less temperature. After 1 year from canister emplacement the temperature differences among canisters can be observed.

The $\pm 20 \mathrm{~m}$ model developed higher maximum temperature values. However, after 1000 years the temperatures are lower in the small or reduced model compared to the large model. Increasing the rock volume produces a temperature response effect with a slower decay. The considered rock volume above and below the canisters (i.e., the distance of the drift to the dissipation boundary) affects the time temperature decay after the peak. As more rock volume is modelled the heat accumulation is larger and heat flux is smaller, implying slower decay. This effect was already studied by Toprak et al. (2013) for the KBS-3V disposal geometry.

It is well known that in numerical model procedures, the natural boundary surfaces shall be sufficiently far away for not disturbing in the analysis. Ideally, a model would require realistic boundary surfaces, for instance the ground surface. However, this may be complicated and inadequate in terms of practical functionality of the model. For the model with boundaries at $\pm 20 \mathrm{~m}$, the temperature variation on the boundary was considered too large and therefore the model with $\pm 100 \mathrm{~m}$ geometry was chosen to perform sensitivity calculations. To make the two models $( \pm 20$ and \pm 100$)$ comparable, the boundary condition on top and bottom was identical with a conductivity coefficient of $\gamma_{\text {heat }}=0.05 \mathrm{~W} /\left(\mathrm{m}^{2} \mathrm{~K}\right)$. This relatively low value is intended to improve the temperature gradients and heat fluxes along the domain. However, the larger rock volume represented in the model $\pm 100 \mathrm{~m}$ cannot be represented by the modification of the boundary conditions of the smaller $\pm 20 \mathrm{~m}$ model.

Figure 6 displays canister temperature evolution for all cases presented in this paper. For the final model $( \pm 100 \mathrm{~m})$, Installation state (with actual gap presence), Initial state (with swollen buffer and closed gap with equivalent properties with the outer buffer block zone), and Homogenized state (both closed gap and buffer inner/outer domain the same properties) cases are presented. Comparison in Figure 6 can be firstly done in terms of domain size as Figures $6 \mathrm{a}$ and $6 \mathrm{c}$ show the Initial state case for \pm 20 and \pm 100 models. Alternatively, comparison can be done in terms of state of the buffer system as Figures $6 b, 6 c$ and $6 d$ show the Installation, Initial and Homogenised state cases, respectively for the final $\pm 100 \mathrm{~m}$ model geometry. In all cases, peak temperatures were obtained at the same canister location ( $3^{\text {rd }}$ canister $)$ and at about the same time $(\approx 20$ years from emplacement of the canisters $)$. The peak temperature is maximum for the $\pm 20 \mathrm{~m}$ model and more pronounced in the logarithmic scale. In this preliminary geometry, cooling takes place consequently faster due to the reduced volume of rock in this model.

The role of the $5 \mathrm{~mm}$ open gap between buffer blocks and rock (i.e., Installation state; Figure $6 \mathrm{~b}$ ) is identified as the maximum temperature is about $+3^{\circ} \mathrm{C}$ higher at about 4 years after canisters emplacement as compared to the Initial state (swollen buffer). This is attributed to the lower conductivity of the gap when it is modelled as an empty space at the beginning which becomes full-filled of water, still with a lower conductivity than the buffer and the rock. As the gap is assumed to have equivalent properties (at both Initial and 
Homogenised state cases), thermal conductivity is higher and temperature variation is lower than at early times in the Installation state case.

The Initial and Homogenised state cases display trends and temperature peak (values and time-location) somewhat similar. However, slightly different temperatures were achieved at times ranging $1-6$ years, with lower values in the Homogenised state case (see Figures 6c and 6d).

A summary of the temperature evolutions for the three cases is shown in Figure 7. Two different areas were shaded according to the canisters with the highest temperature (i.e., $3^{\text {rd }}$ one) and the canisters with the lowest temperature (i.e., $6^{\text {th }}$ and $8^{\text {th }}$ ones: the $6^{\text {th }}$ canister undergoes less temperature up to about 8 years from emplacement of the canisters; but afterwards, the $8^{\text {th }}$ canister undergoes the lower temperature trend). This representation makes possible to determine the predicted/expected maximum and minimum temperature evolution generated through in the drift for the three gap states assumed. The maximum temperature calculated in canisters is always below the maximum temperature calculated by Ikonen and Raiko (2015).

Figure 8 shows temperature evolution for different distances around the $3^{\text {rd }}$ canister (which was the one with the highest temperature). The control points are at different distances from canister center: at buffer block center (about $0.675 \mathrm{~m}$ from canister center), at gap center (about 0.9 from canister center), and at about $2.0 \mathrm{~m}$ from canister center. The three cases returned more similar trends as the distance to the canister increases.

\subsection{Liquid pressure results}

As indicated in Table 2, the initial pore pressure for the Initial state is $-23 \mathrm{MPa}$ at buffer block disks inside the supercontainer, $-37 \mathrm{MPa}$ at buffer block rings inside the supercontainer, and -11.7 MPa for the rest of distance blocks. Figure 9 shows the liquid pressure evolution at two different locations around the canisters: on the middle of the upper lateral-side surface of the buffer blocks above the canisters (left column plots) and on the centre of the right side of the canisters (right column plots). As shown, liquid pressure decreases as temperature increases. This is due to drying of the buffer and the corresponding suction increase but this effect is reversed due to buffer saturation, and becomes smoothly stabilized after about 100 years from canister emplacement. As it can be observed, this liquid pressure decreasing process is different with regards to the cases analysed. In the Homogenized state, the liquid pressure decrease is not as pronounced as in the Installation and Initial state cases, maintaining moderately lower values with respect to the initial state (from -30 to $-40 \mathrm{MPa}$ ).

In contrast, the short- and mid-term results for Installation and Initial state cases got the lowest values, around $-60 \mathrm{MPa}$ for the $3^{\text {rd }}$ and $6^{\text {th }}$ canisters. Liquid pressure results for the right-side end-cylinder centre returned very similar response among the three cases analysed. However, the steady-state value of about $4 \mathrm{MPa}$ was reached 2 years faster in the Initial state as compared with the Installation state, and also about 2 years faster in the Homogenized state case as compared with the Initial state case. Therefore, the Homogenized state reached full saturation at the canister end 4 years earlier than the Installation state. 


\subsection{Saturation degree results}

The discussed effects of buffer-block suction (or liquid pressure) are consistent with the variations of degree of saturation. Figure 10 shows the evolution of the degree of saturation at different control points around the $5^{\text {th }}$ canister, which is the one having closer fractures at both supercontainer sides. The contour field of the saturation degree ranging 0.4 to 1 after 1 year from emplacement of the canisters is also included.

The trends and the minimum degree of saturation are approximately the same at points \#4 and \#5, which are both located next to the canister, and dry first before wetting takes place. Quicker saturation process was achieved in points \#1, \#2 and \#3, located further away from the canister and within the buffer-rock gap. Point \#1 displayed the most significant trending change, where, for the Initial state case, the saturation was reached 4 years faster than for the Installation state case. The explanation is that after a decreasing trend due to the drying process induced by canister heating, suction increased, water was attracted and consequently filled and fully-saturated the buffer blocks (after about 8 years from emplacement of the canisters).

This process and explanation is analogous to the previous liquid pressure results. As it can be observed, the Installation state case (open gap case) generated significant variations at points $\# 1$, \#2, and \#3. These points show much less desaturation for the Initial and Homogenized state cases. For the Installation state (Figure 10a) these three points have lower initial degree of saturation in comparison with the Initial and Homogenized state cases (Figures 10b and $10 \mathrm{c}$, respectively).

However, the assumptions on the gap between the host rock and the buffer blocks, in addition to the location of the observation point with respect to the canister, influences the time to get full saturation. This can be observed with the evolution at Point \#1. Whereas the full saturation takes about one year at Point \#1 for the Initial state, the same process takes about 4 years for the Installation state. This is due to the strong influence of porosity on hydraulic conductivity: the open gap defined at the Installation state has high hydraulic conductivity and vapor diffusivity. Therefore, water can flow practically without restriction through this open gap, but the buffer has lower porosity and lower hydraulic conductivity than at the initial and homogenized state cases, so water can flow more slowly in the buffer at the Installation state than at the Initial and Homogenized state cases. Looking at the contour field of saturation, clearly different distribution was achieved for the three cases analyzed.

\section{DISCUSSION AND CONCLUSIONS}

The presented numerical thermo-hydraulic three-dimensional model to study the spent nuclear fuel disposal provides promising insights for further sensitivity analyses. In the current study, the presence of actual gap condition between the buffer blocks and the host rock resulted in direct effect on KBS-3H behaviour according to the three analysed cases.

The sequential canisters arrangement considering also the presence of rock fractures have a direct effect on temperature distribution through the domain. As it has been shown in the 
present study, canisters emplaced closer to each other generate higher temperature. The presence of fractures which implies larger spacing between the canisters plays a significant role for the heat problem, as it implies that lower temperature was reached.

Modelling the eight-canisters entire-drift domain leads to discretization of the geometry with a large number of nodes and consequent large number of degrees of freedom. A first step to do in numerical modelling is to solve the TH problem. To include the effects of swelling of the buffer blocks on the thermo-hydraulic problem, three cases have been assumed which imply three different states which differentiate on the initial conditions of the engineered materials inside the drift. Additionally, equivalent thermal conductivity was used to eliminate small gaps. The three cases describing different initial conditions of the gap + buffer system were referred to as Installation state (open gap), Initial state (gap filled due to buffer swelling, with the initial density calculated with the mock-up tests available) and Homogenized state (assuming full homogenization, i.e., space between canister and rock filled and the same material properties assumed for the entire buffer). These three cases are intended to represent the states of the real mechanical behaviour, so that the Initial state is between the Installation state and Homogenized state cases. The final state in terms of porosity is expected to be between the Initial state and the Homogenized state.

It can be concluded that, in short-term, the maximum temperature can change between $70.2^{\circ} \mathrm{C}$ and $67.7^{\circ} \mathrm{C}$, corresponding to the maximum canister temperature in Installation state and Initial state, respectively. These temperatures are lower than the maximum temperature of the thermal design, $95^{\circ} \mathrm{C}$ (Ikonen and Raiko, 2015). This temperature is calculated in very conservative hypothesis: all gaps are open and filled with air and the distance between canisters centres is $9 \mathrm{~m}$ (in the current model, 1-2-3-4 and 7-8 canisters are spaced by $9 \mathrm{~m}$ ). Canister spacing could be optimized with regards of the presence of fractures. If a faster gap closure takes place the supercontainers could be installed closer. In mid- and long-term (between Initial state and Homogenized state) buffer porosity changes moderately, so temperature and liquid pressure are not affected. Therefore, the prediction of the maximum temperature and minimum liquid pressure (related with the largest saturation time) can be done without solving the mechanical problem. This simplifies the calculation especially avoiding the buffer swelling process modelling through the supercontainer shell. Thus, from the achieved results, the Initial state seems to be a good first-approximation strategy to avoid modelling of the gap filling mechanical process. However, it should be studied in greater detail, especially when more information from mock-up tests will be available. In any case, further analyses should be done once tests are dismantled and properly reported, confirming the model concept and parameters used.

The liquid pressure results demonstrate the effect of the Homogenized state, with a clear reduction of the suction pressures reached in contrast to the Installation and Initial state cases at the radial lateral canister side location. After the minimum liquid pressure is achieved (at about 1 year from the emplacement of the canisters) and water fills the buffer blocks, pressure smoothly tends to a stable value of about $4.2 \mathrm{MPa}$ at about 100 years from emplacement of canisters. Related to the liquid pressure calculations, results also indicate that the main saturation process ( $S_{1}$ up to 0.96 ) takes place during the first ten years. Then, the full saturation is achieved in a smoother manner through 50-100 years and remains saturated up to the end of the calculation (i.e., 1000 years). 


\section{ACKNOWLEDGEMENTS}

3 This work was supported by Posiva Oy and SKB AB. The authors acknowledge Lasse

4 Koskinen (Posiva Oy), Margit Snellman and Pirjo Hellä (Saanio \& Riekkola Oy) for their 5 technical and administrative assistance.

6 


\section{REFERENCES}

Asensio, L., 2013. Hydro-mechanical elastoplastic model of expansive bentonite behaviour in free swelling conditions. PhD dissertation. Universidad de Castilla-La Mancha. Ciudad Real. Spain.

CODE_BRIGHT, DECA-UPC / CIMNE, 2017. Department of Civil and Enviromental Engineering (School of Civil Engineering), Universitat Politècnica de Catalunya / International Center for Numerical Methods in Engineering.

https://deca.upc.edu/ca/el-departament/seccions/etcg/recerca/projectes/code_bright

https://www.gidhome.com/gid-plus/modules/modules-research/27/codebright/

Enresa, 2000. FEBEX project. Full-scale engineered barriers experiment for a deep geological repository for high level radioactive nuclear waste in crystalline rock. Technical publication 1/2000. Madrid, Spain.

Gens, A., Garcia-Molina, A. J., Olivella, S., Alonso, E. E. and Huertas, F., 1998. Analysis of a full scale in situ test simulating repository conditions. Int. J. Numer. Anal. Methods Geomech. 22, No. 7, 515-548.

Gens, A., M. Sanchez, L. DO N. Guimaraes, E. E. Alonso, A. Lloret, S. Olivella, M. V. Villar and F. Huertas, 2009. A full-scale in situ heating test for high-level nuclear waste disposal: observations, analysis and interpretation, Geotechnique 59, No. 4, 377-399.

Gens, A. and Alonso, E.E., 1992. A framework for the behaviour of unsaturated expansive clays. Canadian Geotechnical Journal 29(6): 1013-1032. doi: 10.1139/t92-120.

GID-CIMNE, 2017. GID - The personal pre and post processor. https://www.gidhome.com

Ikonen, K. and Raiko, H., 2015. Thermal analysis of KBS-3H repository. Posiva working report 2015-01. Eurajoki, Finland.

Juvankoski, M. and Marcos, N., 2010. Design Basis for Buffer Components. Posiva Working report 2009-132, Eurajoki, Finland.

Kristensson, O., Sandén, T., Börgesson, L., and Åkesson, M., 2016. Summary report - KBS3H Buffer Laboratory Tests. SKB report P-16-17. Stockholm, Sweden.

Olivella, S., Gens, A., Carrera, J., and Alonso, E.E., 1996. Numerical formulation for a simulator (CODE-BRIGHT) for the coupled analysis of saline media. Engineering Computations 1: 87- 112 . 
1 Pintado, X., Schatz, T., and García-Siñeriz, J-L, 2015. Initial data report for the Multi Purpose

2 Test. SKB P-15-03. Stockholm. Sweden.

3

4

Pintado, X., Schatz, T., García-Siñeriz, J-L, and De la Rosa, C., 2016a. KBS-3H. Second Data Report for the Multi-Purpose Test. SKB P-16-16. Stockholm. Sweden.

Pintado, X., Kristensson, O., Malmberg, D., Åkesson, M., Olivella, S., and Damians, I.P., 2016b; TH and THM Modelling of a KBS-3H Deposition Drift. Posiva Working report 201625, Eurajoki, Finland, 2017.

Posiva Oy, 2009. Olkiluoto Site Description 2008, Posiva Report 2009-01, Eurajoki, Finland.

Posiva Oy, 2012. Olkiluoto Site Descripton 2011. Posiva report 2011-02. Eurajoki, Finland.

Posiva and SKB, 2017. KBS-3H System Design Phase 2011-2016: Final Report. Report 06 Posiva; SKB. Eurajoki, Finland.

Toprak, E., Mokni, N., Olivella, S., and Pintado, X., 2013. Thermo-Hydro-Mechanical Modelling of Buffer, Synthesis Report, Posiva Report 2012-47, Eurajoki, Findland.

Sánchez, M., Gens, A., Villar, M.V., and Olivella, S., 2016. A Fully Coupled THM Double Porosity Formulation for Unsaturated Soils, International journal of geomechanics, Vol 16, 10.1061/(ASCE)GM.1943-5622.0000728.

Sandén, T., Börgesson, L., Dueck, A., Goudarzi, R., Lönqvist, M., Nilsson, U., and Åkesson, M., 2008. KBS-3H. Description of laboratory tests. SKB Report R-08-40. Stockholm, Sweden.

SKB, 2010a. Design, production and initial state of the closure. SKB Technical report TR-1017, Stockholm, Sweden.

SKB, 2010b. Buffer, backfill and closure process report for the safety assessment SR-site. SKB Technical report TR-10-47, Stockholm, Sweden.

STUK, 2015. Decision about the license application presented by Posiva for the construction of a spent nuclear fuel in Olkiluoto. Document 1/H42252/2015. Helsinki, Finland. 


\section{$1 \quad$ Figures and Tables}

a)

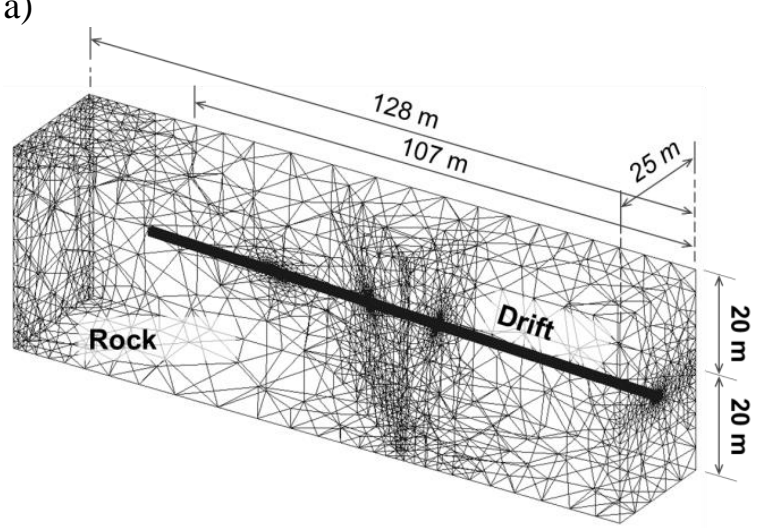

c)

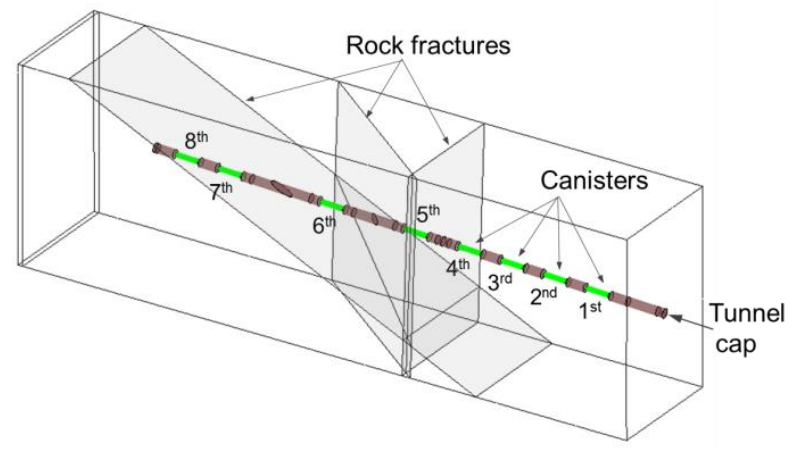

b)

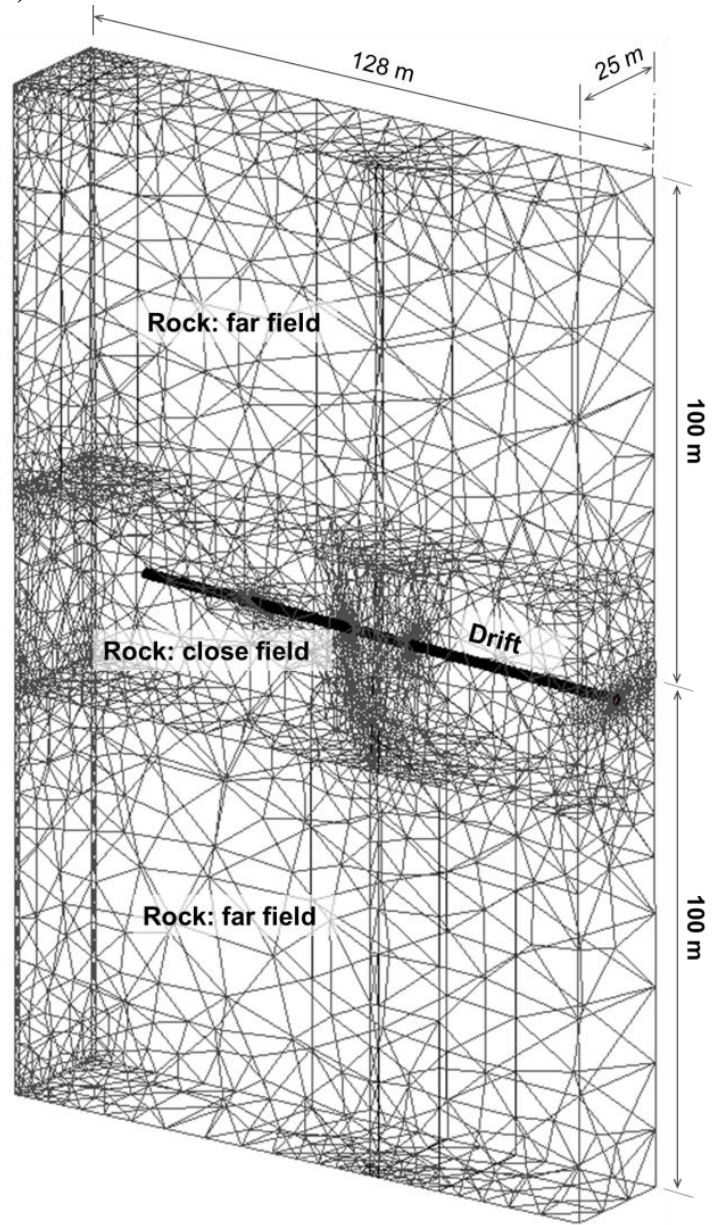

6 Figure 1. Entire drift 3D model mesh and main geometry dimensions: (a) preliminary $\pm 20 \mathrm{~m}$ version, (b) final $\pm 100 \mathrm{~m}$ version used, and (c) numbered canisters location and rock fractures detail. 
a)

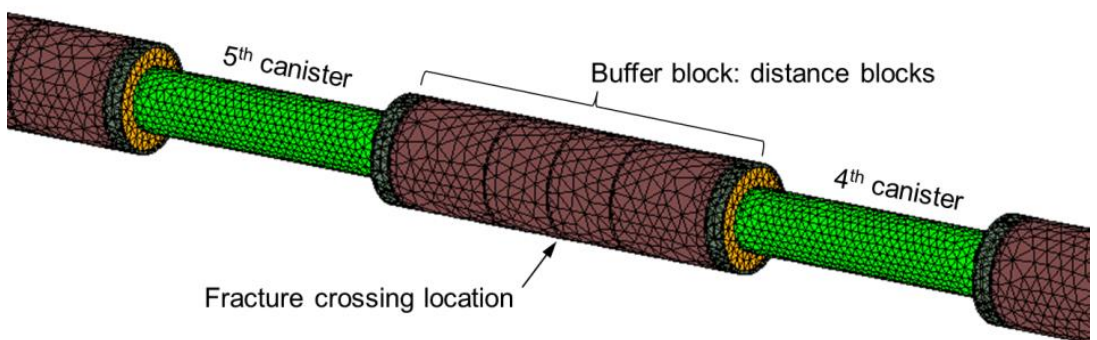

b)

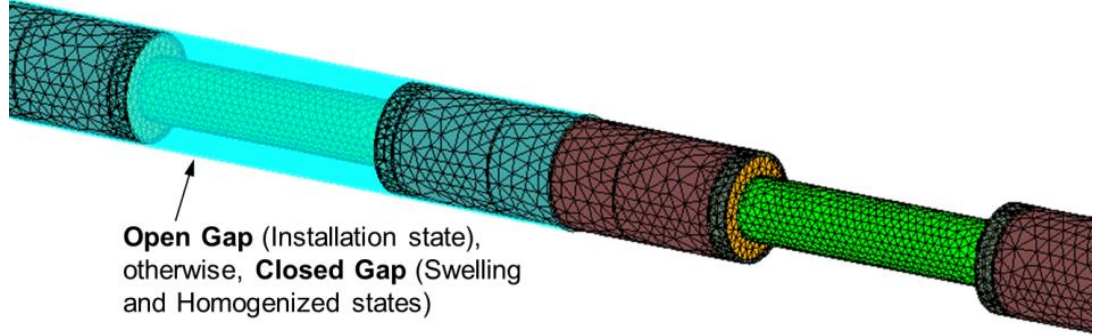

c)
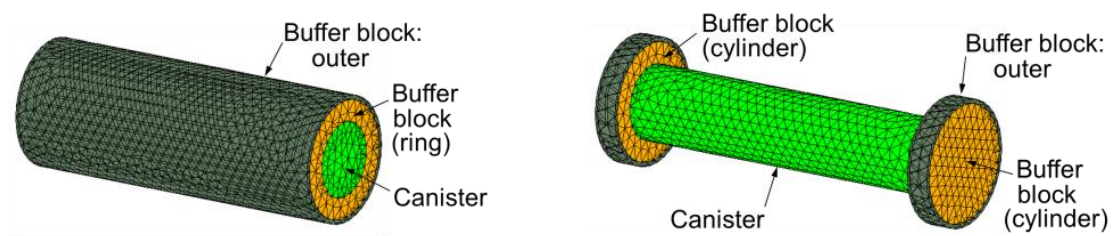

2 Figure 2. Drift canister-to-canister (a) mesh detail, (b) gap detail, and (c) super-container components. 3 
a) Installation state:

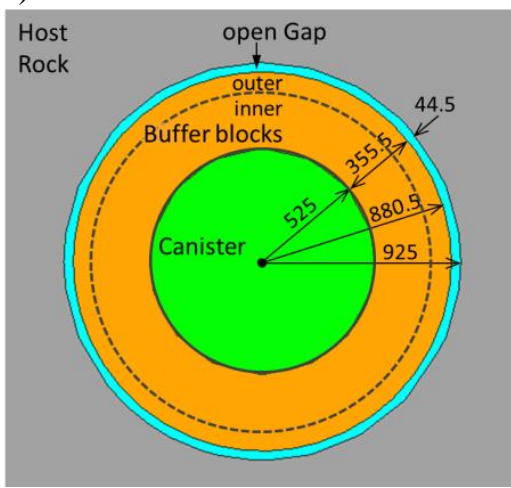

b) Initial state:

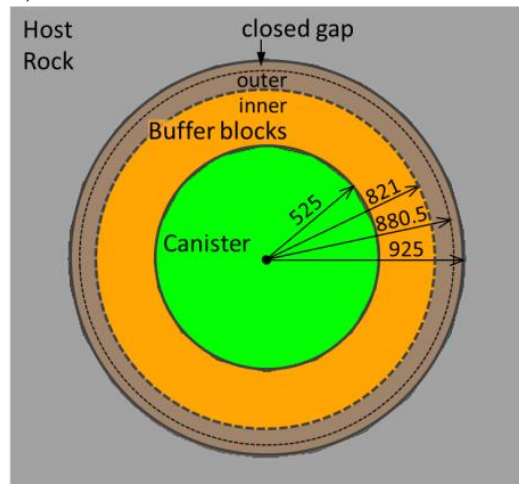

c) Homogenized state:

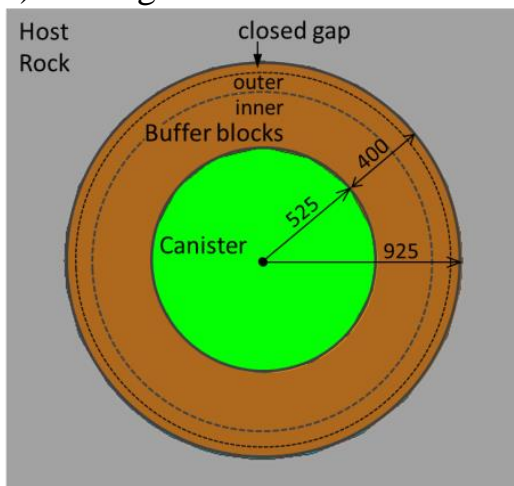

2 Figure 3. Super container cross-section geometry: (a) Installation, (b) Initial, and (c) Homogenized 3 state cases. (measurements in $\mathrm{mm}$ ). 
2 Table 1. Material properties at initial conditions.

\begin{tabular}{|c|c|c|c|c|c|c|c|}
\hline \multirow{3}{*}{\multicolumn{2}{|c|}{ Parameters }} & \multirow{2}{*}{\multicolumn{5}{|c|}{ Materials: }} & \multirow[b]{3}{*}{ Units } \\
\hline & & & & & & & \\
\hline & & Host rock & Fractures & Buffer blocks & Gap & $\begin{array}{c}\text { Caniste } \\
\mathrm{r}\end{array}$ & \\
\hline \multicolumn{2}{|l|}{ Porosity } & 0.005 & 0.005 & $\left(\right.$ see Table 2) ${ }^{(a)}$ & $\left(\right.$ see Table 2) $^{(a)}$ & 0.01 & - \\
\hline \multicolumn{2}{|l|}{$\begin{array}{l}\text { Intrinsic } \\
\text { Permeability, } k\end{array}$} & $\begin{array}{l}1.52 \times 10^{-19} \text { at } \\
\text { close field, } \\
1.52 \times 10^{-17} \text { at } \\
\text { far field }\end{array}$ & $10^{-15(\mathrm{c})}$ & $\begin{array}{c}k_{0}= \\
5.59 \times 10^{-21} \\
\text { (d) }\end{array}$ & $\begin{array}{l}\text { Installation: } \\
\quad 10^{-16(\mathrm{e})} \\
\text { Initial \& } \\
\text { Homogenized: } \\
k_{0}=5.59 \times 10^{-21(\mathrm{~d})}\end{array}$ & $10^{-24}$ & $\mathrm{~m}^{2}$ \\
\hline \multirow{2}{*}{$\begin{array}{l}\text { Water retention } \\
\text { curve }^{(\mathrm{f})}\end{array}$} & $P_{0}$ & 1.5 & 1.5 & 27 & 0.05 & 31.25 & $\mathrm{MPa}$ \\
\hline & & 0.3 & 0.3 & 0.45 & 0.3 & 0.5 & - \\
\hline \multicolumn{2}{|c|}{ Relative permeability, $k_{\mathrm{rl}}{ }^{(\mathrm{g})}$} & 3 & 3 & 3 & 3 & 3 & $n$-power \\
\hline \multirow{2}{*}{$\begin{array}{l}\text { Thermal } \\
\text { conductivity }^{(\mathrm{h})}\end{array}$} & $\begin{array}{l}\text { Dry, } \\
\lambda_{\text {dry }}\end{array}$ & 2.82 & 2.82 & 0.22 & $\begin{array}{l}\text { Install.: } 0.02 \\
\text { Initial \& } \\
\text { Homog.: } 0.22\end{array}$ & 390 & $\mathrm{~W} /(\mathrm{mK})$ \\
\hline & $\begin{array}{l}\text { Saturated, } \\
\lambda_{\text {sat }}\end{array}$ & 2.82 & 2.82 & 1.25 & $\begin{array}{l}\text { Install.: } 0.6 \\
\text { Initial \& } \\
\text { Homog.: } 1.25\end{array}$ & 390 & $\mathrm{~W} /(\mathrm{mK})$ \\
\hline \multicolumn{2}{|c|}{ Solid unit weight, $\gamma_{\mathrm{s}}$} & 2743 & - & 2780 & $\begin{array}{l}\text { Install.: } 0 \\
\text { Initial \& } \\
\text { Homog.: } 2780 \\
\end{array}$ & 8930 & $\mathrm{~kg} / \mathrm{m}^{3}$ \\
\hline \multicolumn{2}{|l|}{$\begin{array}{l}\text { Solid phase } \\
\text { specific heat, } c_{\mathrm{s}}\end{array}$} & 746 & - & 830 & 1000 & 390 & $\mathrm{~J} /(\mathrm{kgK})$ \\
\hline \multicolumn{2}{|c|}{ Liquid pressure, $P_{1}$} & hydrostatic $^{(i)}$ & hydrostatic $^{(i)}$ & $(\text { see Table } 2)^{(a)}$ & $(\text { see Table } 2)^{(a)}$ & -20 & $\mathrm{MPa}$ \\
\hline \multicolumn{2}{|c|}{ Temperature, $T$} & 10.5 & 10.5 & 10.5 & 10.5 & 50 & ${ }^{\circ} \mathrm{C}$ \\
\hline
\end{tabular}

Notes: (a) Properties depending on actual time state (i.e., "installation" state, otherwise "initial" of homogenized states, are state-distinctions that relate to different idealized temporary cases), which also affects them material definition (e.g., "closed gap" is featuring actual "open gap" ( $\phi$ $=0.99$ ) at installation state, but has properties of expanded block at initial state). See Table 2 for material properties definition of these components

(b) Higher value of permeability at far-field rock material (i.e., from $20 \mathrm{~m}$ up to $100 \mathrm{~m}$ above and below the tunnel) to take into account the network fracture capacity to keep the pressure almost constant at $20 \mathrm{~m}$ from the axis drift;

(c) Fracture representation considers a default thickness $t=0.001 \mathrm{~m}$. Thus, the consequent intrinsic transmissivity is given by $k t=10^{-18} \mathrm{~m}^{3}$;

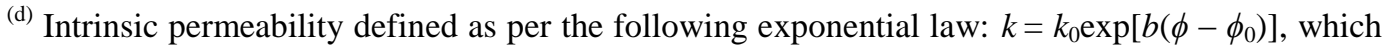
returns $k_{0}=5.59 \times 10^{-21}$ (for $b=15$ and $\phi_{0}=0.438$ );

${ }^{(e)}$ Fixed value, i.e., constant permeability at installation state;

(f) Water retention curve according to Van Genuchten model ( $\lambda$ : shape function);

${ }^{(\mathrm{g})}$ Relative permeability $k_{\mathrm{rl}}=\left(S_{1}\right)^{n}$, where $S_{1}$ : saturation degree;

(h) Linear law of thermal conductivity, assuming refined equivalent-interpolated values for Buffer blocks and Gap materials from harmonic mean equation development (see explanations from Equations 1 and 2);

(i) Hydrostatic-linear law from 3.25 MPa (top) to 5.25 MPa (bottom boundary), i.e., assuming the drift located at $425 \mathrm{~m}$-depth. 
2 Table 2. Installation, initial and homogenized states initial porosity $(\phi)$, saturation degree $\left(S_{1}\right)$, and 3 liquid pressure $\left(P_{1}\right)$ for buffer block drift components.

\begin{tabular}{|c|c|c|c|c|c|c|c|c|c|c|}
\hline \multirow{3}{*}{$\begin{array}{l}\text { States } \\
\text { Installation }\end{array}$} & \multicolumn{9}{|c|}{ Buffer block material components: } & \multirow[b]{3}{*}{ Units } \\
\hline & \multicolumn{3}{|c|}{ Buffer block: Cylinder } & \multicolumn{3}{|c|}{ Buffer block: Ring } & \multicolumn{3}{|c|}{ Distance block } & \\
\hline & \multicolumn{2}{|c|}{$\begin{array}{l}\text { entire block } \\
\text { thickness }\end{array}$} & $\begin{array}{c}\text { open } \\
\text { gap }\end{array}$ & \multicolumn{2}{|c|}{$\begin{array}{l}\text { entire block } \\
\text { thickness }\end{array}$} & $\begin{array}{c}\text { open } \\
\text { gap }\end{array}$ & \multicolumn{2}{|c|}{$\begin{array}{l}\text { entire block } \\
\text { thickness }\end{array}$} & $\begin{array}{c}\text { open } \\
\text { gap }\end{array}$ & \\
\hline$\Phi$ & \multicolumn{2}{|c|}{0.369} & 0.99 & \multicolumn{2}{|c|}{0.322} & 0.99 & \multicolumn{2}{|c|}{0.384} & 0.99 & - \\
\hline$S_{1}$ & \multicolumn{2}{|c|}{0.807} & 1 & \multicolumn{2}{|c|}{0.644} & 1 & \multicolumn{2}{|c|}{0.936} & 1 & - \\
\hline$P_{1}$ & \multicolumn{2}{|c|}{-23} & 0.1 & \multicolumn{2}{|c|}{-37} & 0.1 & \multicolumn{2}{|c|}{-11.7} & 0.1 & $\mathrm{MPa}$ \\
\hline Initial & $\begin{array}{l}\text { block- } \\
\text { inner }\end{array}$ & $\begin{array}{l}\text { block- } \\
\text { outer }\end{array}$ & $\begin{array}{l}\text { closed } \\
\text { gap }\end{array}$ & $\begin{array}{l}\text { block- } \\
\text { inner }\end{array}$ & $\begin{array}{l}\text { block- } \\
\text { outer }\end{array}$ & $\begin{array}{l}\text { closed } \\
\text { gap }\end{array}$ & $\begin{array}{l}\text { block- } \\
\text { inner }\end{array}$ & $\begin{array}{l}\text { block- } \\
\text { outer }\end{array}$ & $\begin{array}{l}\text { closed } \\
\text { gap }\end{array}$ & \\
\hline$\Phi$ & 0.369 & \multirow{2}{*}{\multicolumn{2}{|c|}{$\begin{array}{l}0.689 \\
0.861\end{array}$}} & 0.322 & \multirow{2}{*}{\multicolumn{2}{|c|}{$\begin{array}{l}0.689 \\
0.805\end{array}$}} & 0.384 & \multirow{2}{*}{\multicolumn{2}{|c|}{$\begin{array}{l}0.664 \\
0.961\end{array}$}} & - \\
\hline$S_{1}$ & 0.807 & & & 0.644 & & & 0.936 & & & - \\
\hline$P_{1}$ & -23 & -18.5 & 0.1 & -37 & -23 & 0.1 & -11.7 & -9 & 0.1 & $\mathrm{MPa}$ \\
\hline Homogenized & \multicolumn{2}{|c|}{$\begin{array}{l}\text { entire block } \\
\text { thickness }\end{array}$} & $\begin{array}{l}\text { closed } \\
\text { gap }\end{array}$ & \multicolumn{2}{|c|}{$\begin{array}{c}\text { entire block } \\
\text { thickness }\end{array}$} & $\begin{array}{l}\text { closed } \\
\text { gap }\end{array}$ & \multicolumn{2}{|c|}{$\begin{array}{c}\text { entire block } \\
\text { thickness }\end{array}$} & \multicolumn{2}{|l|}{$\begin{array}{l}\text { closed } \\
\text { gap }\end{array}$} \\
\hline$\Phi$ & \multicolumn{3}{|c|}{0.442} & \multicolumn{3}{|c|}{0.442} & \multicolumn{3}{|c|}{0.439} & - \\
\hline$S_{1}$ & 0.795 & \multicolumn{2}{|c|}{1} & 0.611 & \multicolumn{2}{|c|}{1} & 0.993 & \multicolumn{2}{|c|}{1} & - \\
\hline$P_{1}$ & -23 & -18.5 & 0.1 & -37 & -23 & 0.1 & -11.7 & -9 & 0.1 & $\mathrm{MPa}$ \\
\hline
\end{tabular}


a)

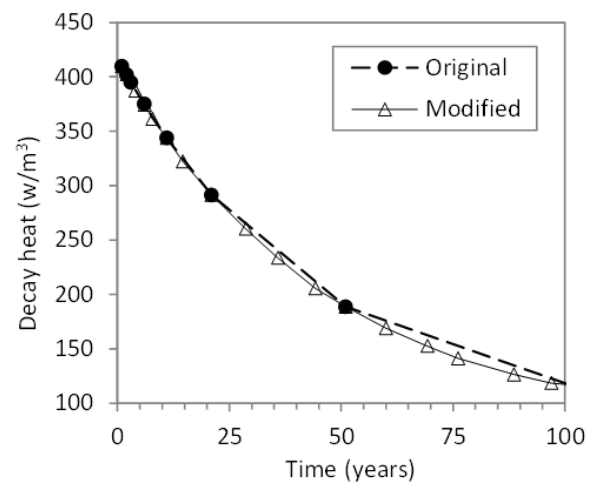

b)

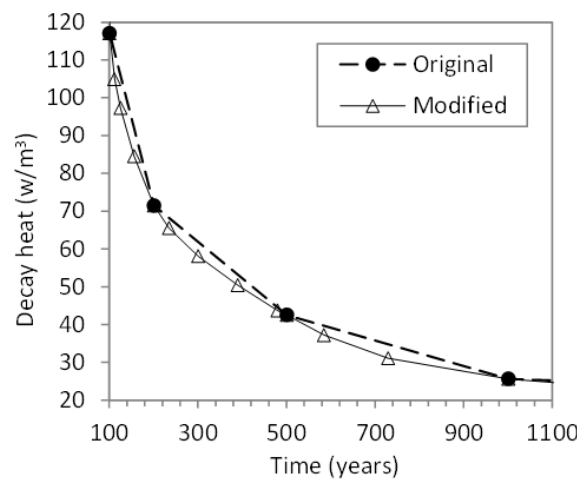

2 Figure 4. Decay power function. Comparison of smoothed line with data values from Ikonen and 3 Raiko (2015): (a) from 0 to 100 years, and (b) from 100 to 1100 years.

4 
a)

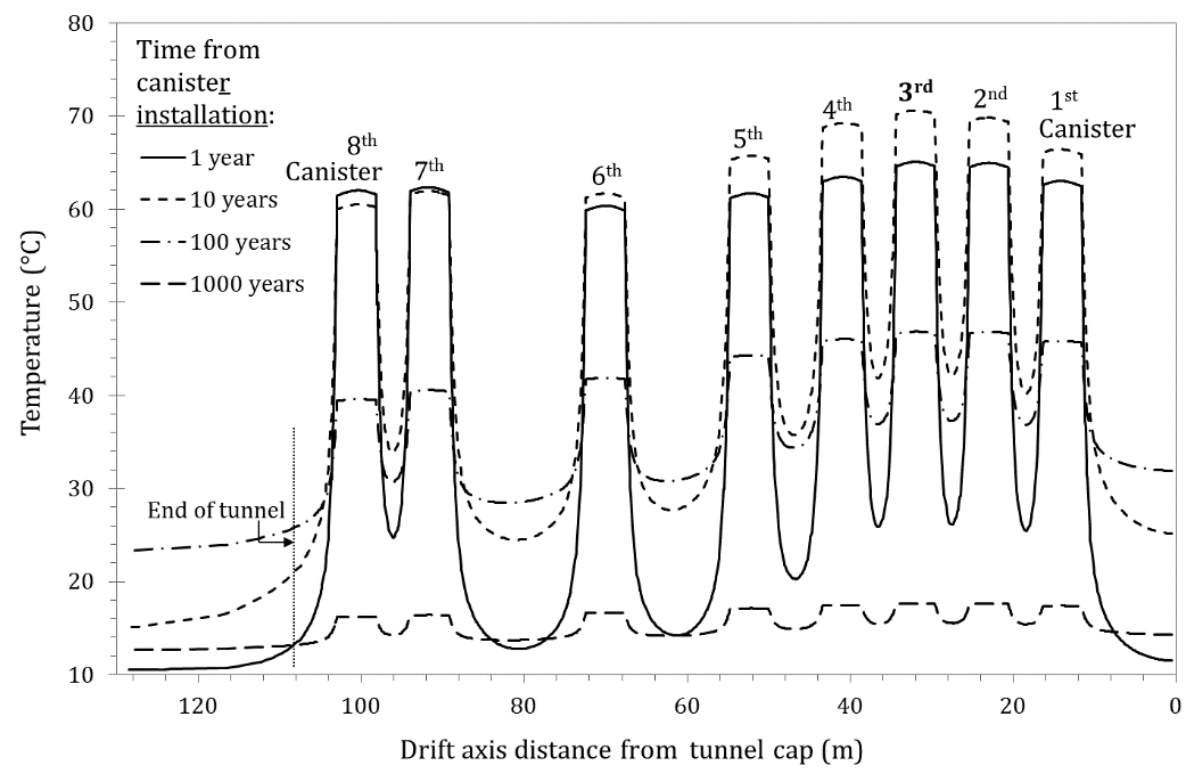

b)

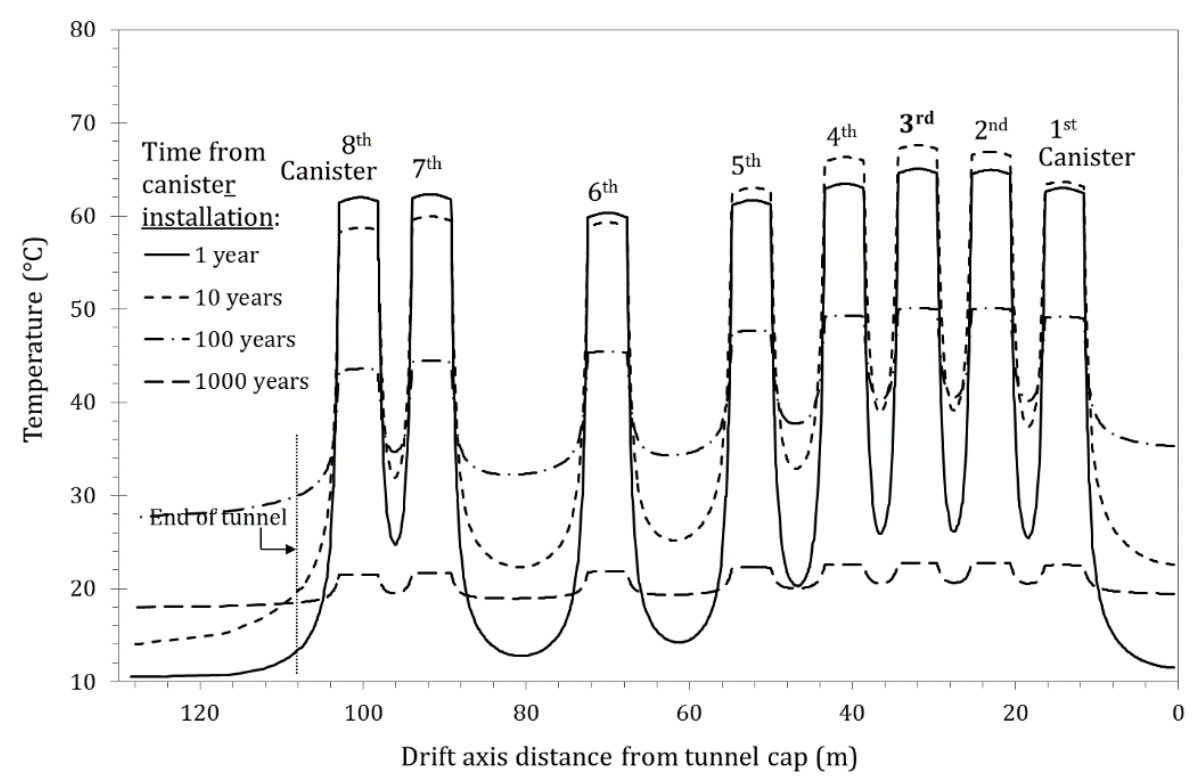

2 Figure 5. Temperature distribution through drift axis at Initial state: (a) $\pm 20 \mathrm{~m}$ rock-thickness 3 preliminary model, and (b) $\pm 100 \mathrm{~m}$ rock-thickness final model. 
a) Preliminary model $( \pm 20 \mathrm{~m})$ : Initial state

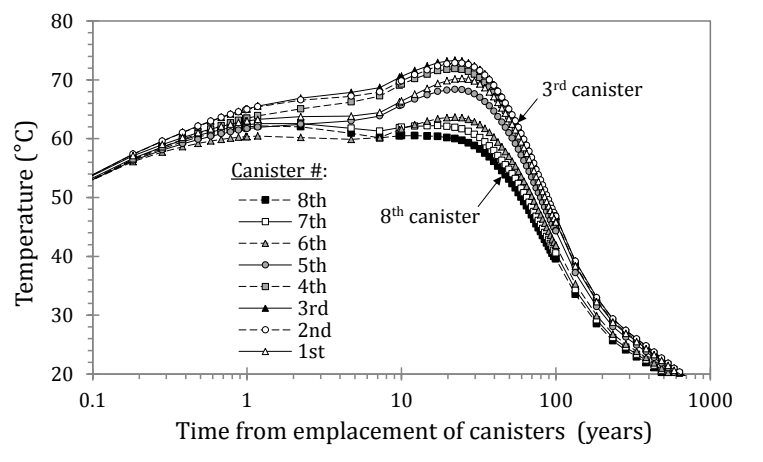

c) Final model ( $\pm 100 \mathrm{~m})$ : Initial state

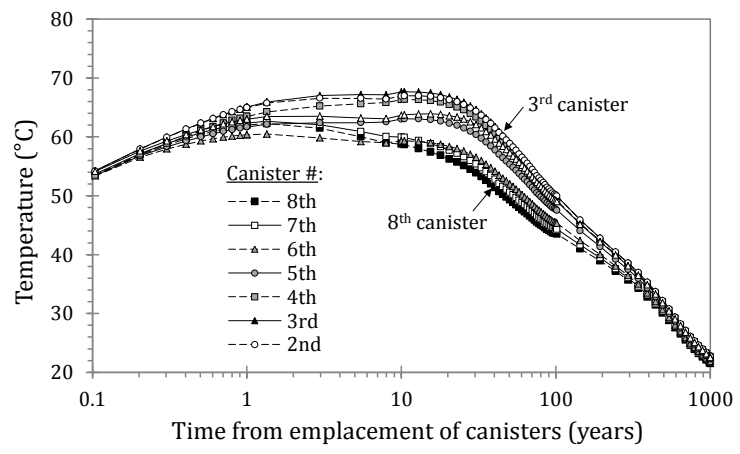

b) Final model $( \pm 100 \mathrm{~m})$ : Installation state

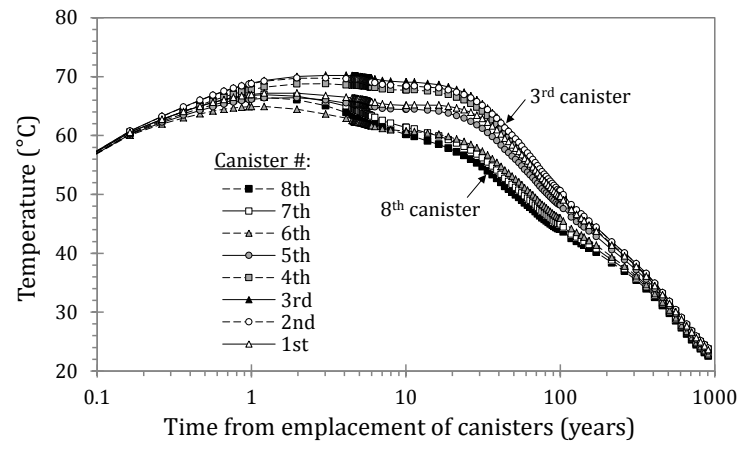

d) Final model ( $\pm 100 \mathrm{~m})$ : Homogenized state

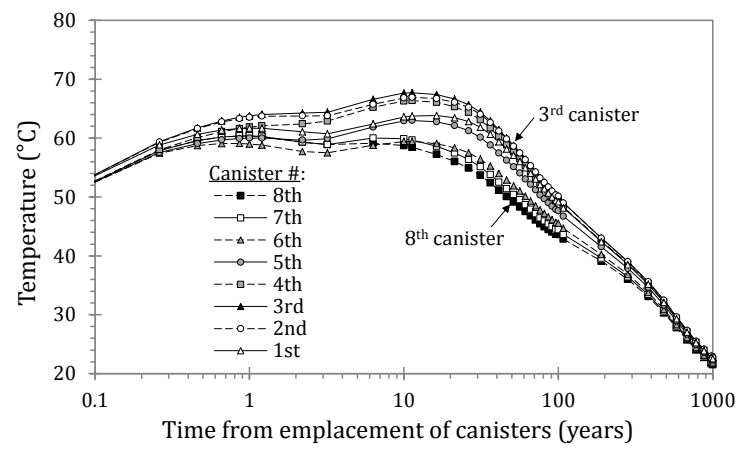

2 Figure 6. Temperature evolution at canisters center: (a) Preliminary model ( $\pm 20 \mathrm{~m})$ Initial state, and 3 Final model ( $\pm 100 \mathrm{~m}$ ) for (b) Installation, (c) Initial, and (d) Homogenized state cases. 


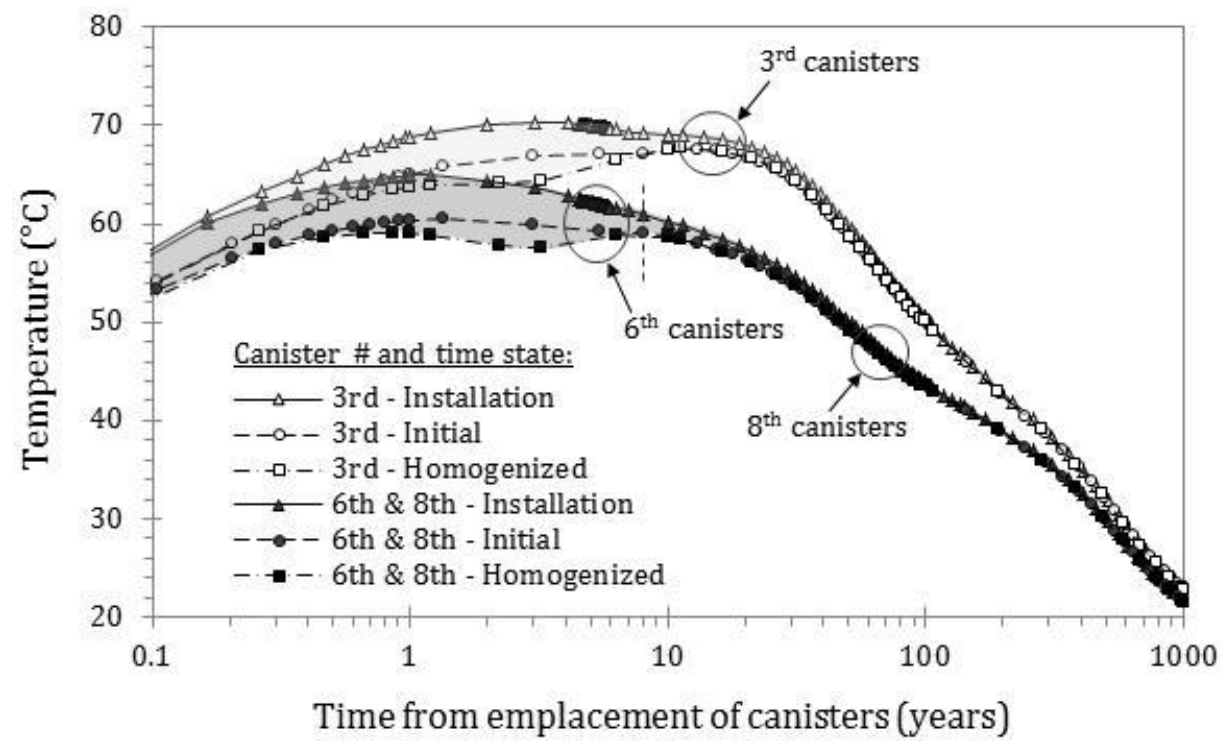

2 Figure 7. Summary of temperature evolution at $3^{\text {rd }}$ and $8^{\text {th }}$ canisters center: Ranging zone of 3 temperature evolution with regards to Installation, Initial and Homogenized state cases 


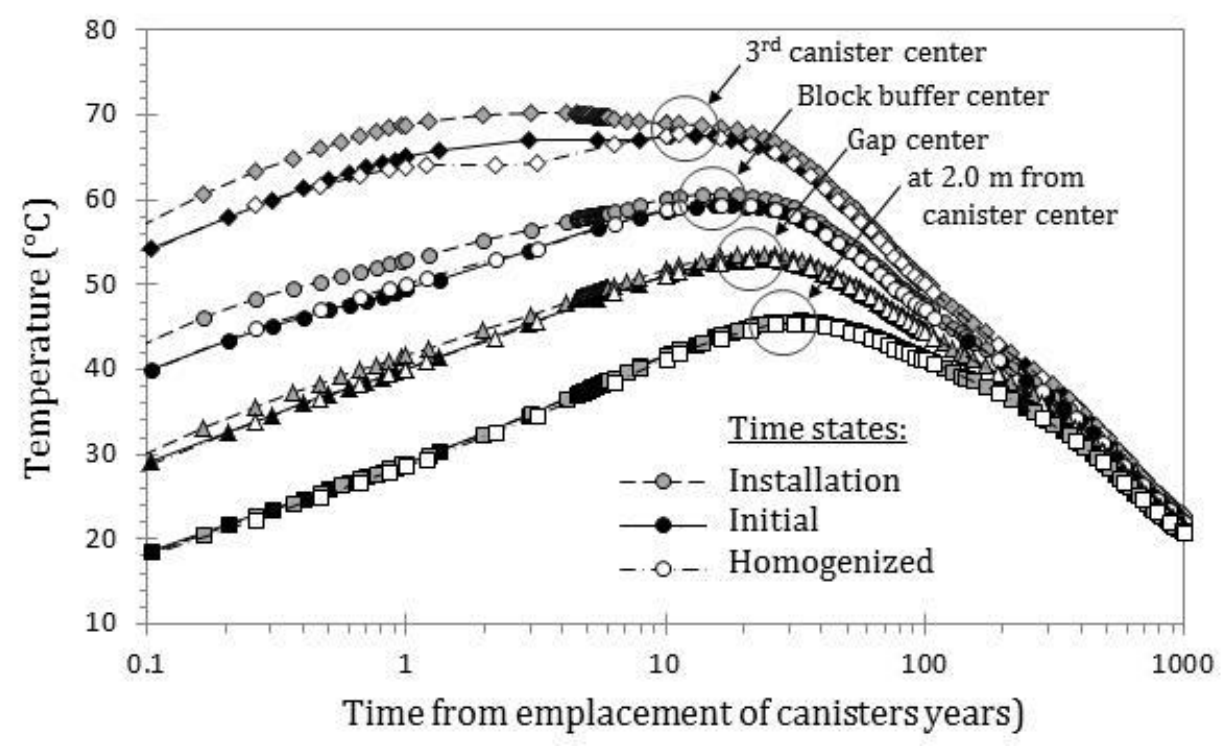

2 Figure 8. Temperature evolution at several radial distances from $3^{\text {rd }}$ canister and different cases 3 
a)

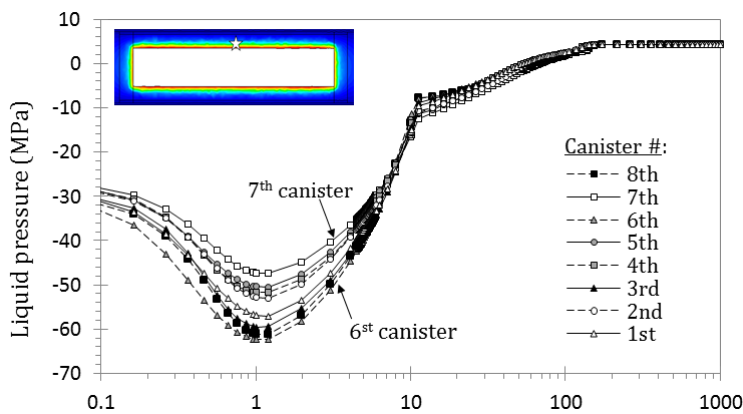

b)

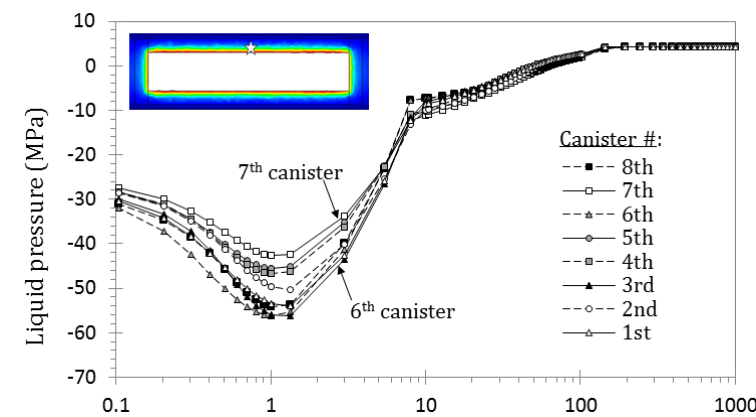

c)

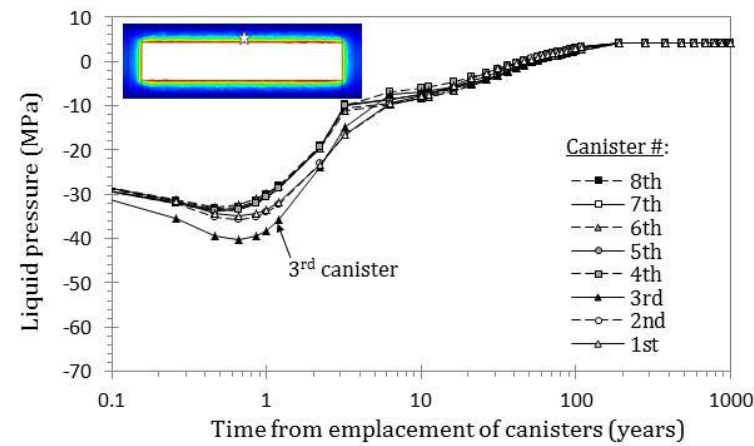

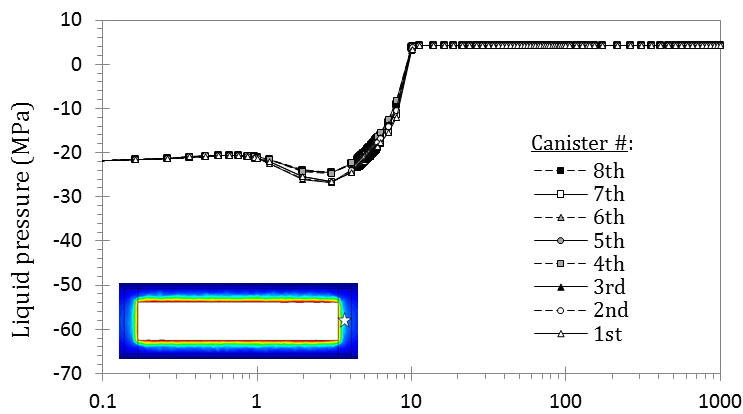
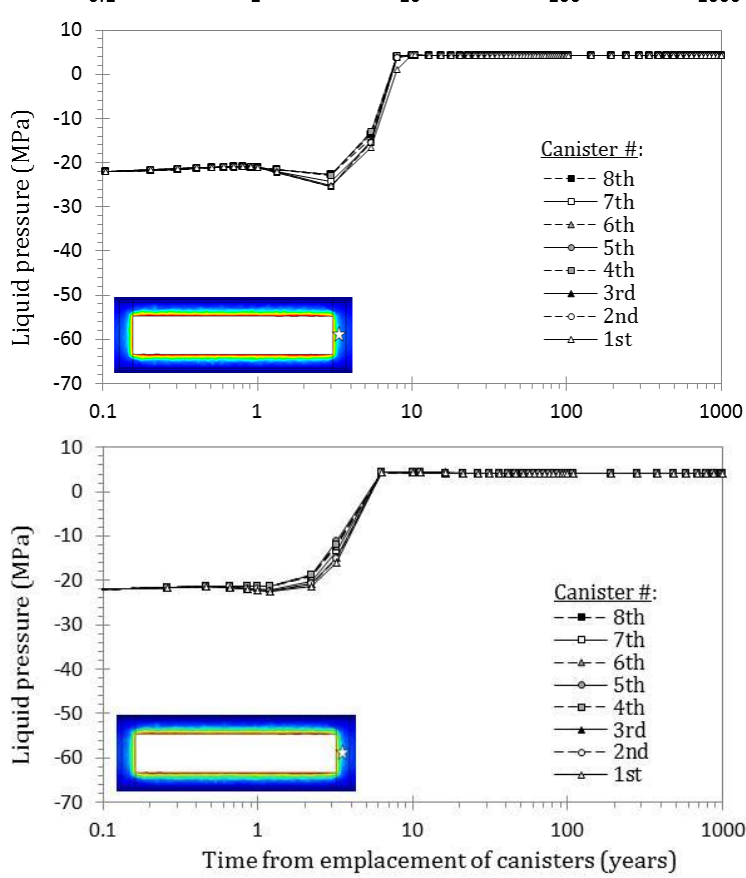

3 Figure 9. Liquid pressure at upper-lateral side canister surface (left column plots) and at canister rightside end-cylinder center (right column plots) for (a) Installation, (b) Initial, and (c) Homogenized state cases. 
a)
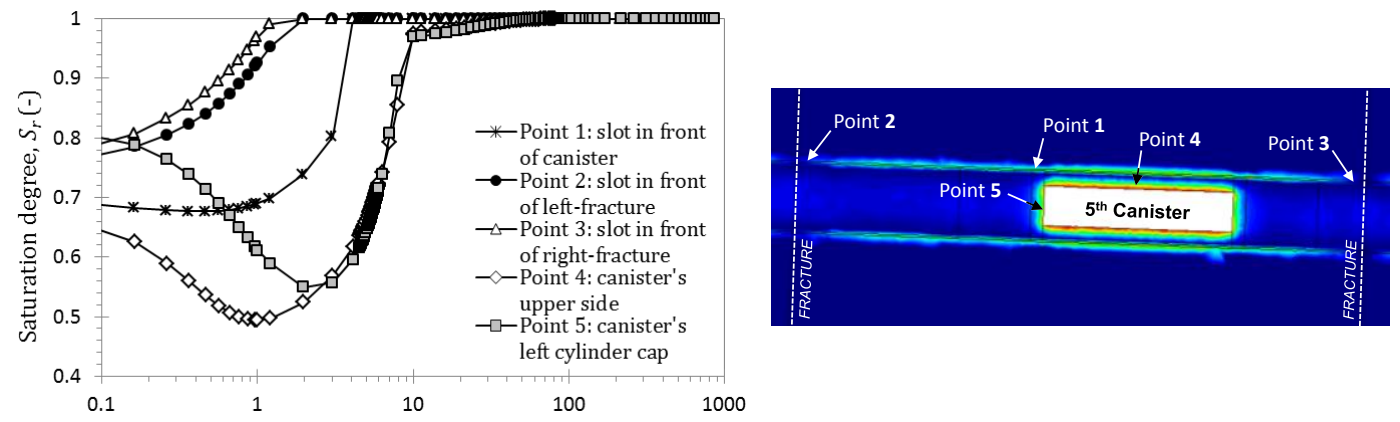

Liq Sat Deg 1
0.93333
0.86667 0.8
-0.73333
0.66667 0.66667
0.6
0.53333
0.46667

b)
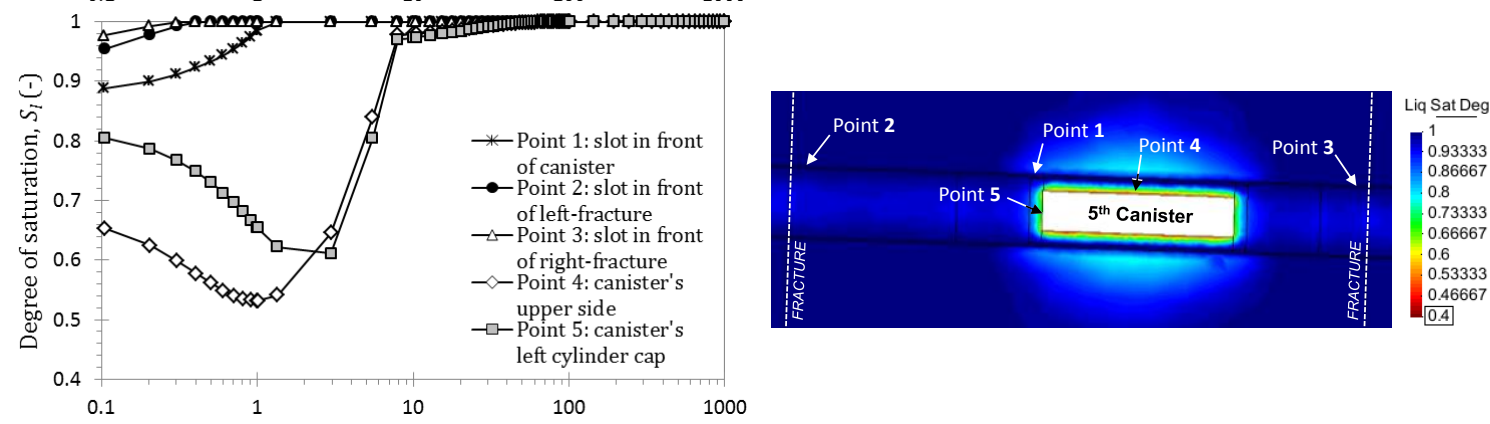

c)
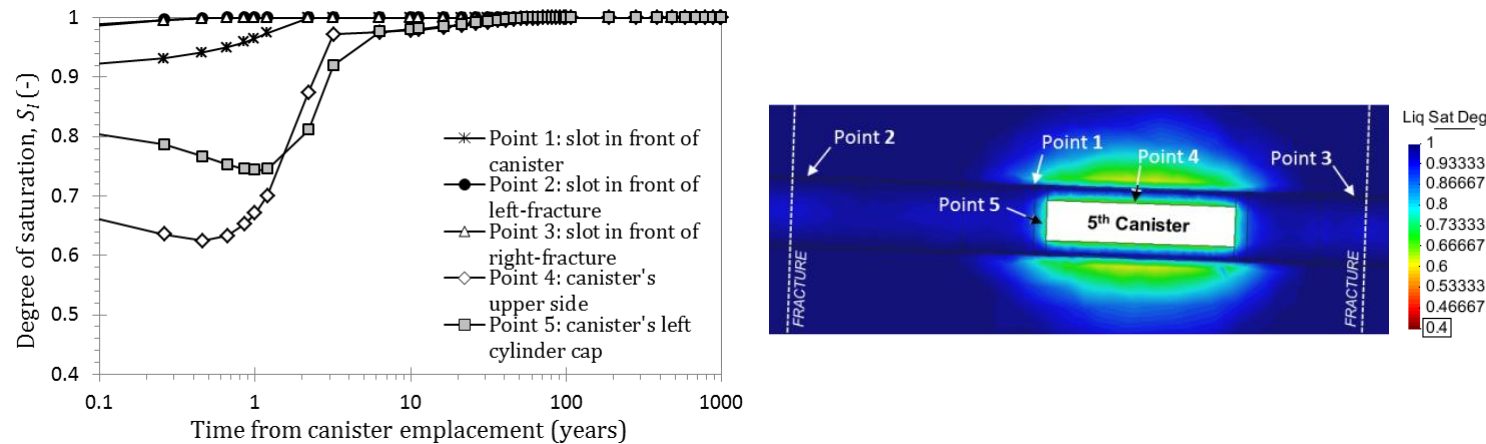

Figure 10. Saturation degree at several points around $5^{\text {th }}$ canister: (a) Installation, (b) Initial, and (c) Homogenized state cases with contour field figures after 1 year from the emplacement of the canisters (all figures ranging $S_{l}$ from 0.4 to 1.0 ). 